\title{
Thematic issue: water of the Erhai and Dianchi Lakes
}

\author{
Shengrui Wang ${ }^{1} \cdot$ Binghui Zheng $^{1} \cdot$ Cui Chen ${ }^{2} \cdot$ Max Dohmann $^{3} \cdot$ Olaf Kolditz $^{4}$
}

Received: 15 July 2015/ Accepted: 21 July 2015/Published online: 8 August 2015

(C) Springer-Verlag Berlin Heidelberg 2015

Eutrophication of surface waters is a severe problem worldwide (Dimberg and Bryhn 2014; Harmon et al. 2014; Christia et al. 2014; Renjith et al. 2013; Sedlacek et al. 2013; Antunes et al. 2013; Rinke et al. 2013; Watchorn et al. 2013; George et al. 2013; Ivashechkin et al. 2004) but particularly important to China because of the use of water resources from the huge rivers originating in the Tibetan plateau flowing through the North China Plain into the Pacific Ocean. The water quality issue includes nutrients (Ji et al. 2014; Wu et al. 2013) and phosphorus (Chen et al. 2014; Yuan et al. 2014; Zhu et al. 2013; Liu and Chang 2013; Marjore et al. 2013).

Recent thematic Issues in EES were dealing with Integrated Water Resources Management under different hydrological, climatic and socio-economic conditions (Kalbus et al. 2012; Grathwohl et al. 2013) including topics like progress in monitoring and modelling concepts

Olaf Kolditz

ees-editor@ufz.de

1 Chinese Research Academy of Environmental Sciences, Dayangfang 8, Anwai Beiyuan, Chaoyang District, 100012 Beijing, China

2 Department of Environmental Informatics (ENVINF), Helmholtz Centre for Environmental Research (UFZ), Sino-German Research Centre for Environmental Information Science (RCEIS), Permoserstraße 15, 04318 Leipzig, Germany

3 Institute of Environmental Engineering RWTH Aachen, Kackertstr. 15-17, 52074 Aachen, Germany

4 Department of Environmental Informatics (ENVINF), Helmholtz Centre for Environmental Research (UFZ), Applied Environmental Systems Analysis (TU Dresden), Sino-German Research Centre for Environmental Information Science (RCEIS), Permoserstraße 15, 04318, Leipzig, Germany
(Beinhorn et al. 2005; Beyer et al. 2006; Kalbacher et al. 2012; Rink et al. 2012) and the aquatic ecosystem functions (the harm of microcystis aeruginosa, role of macrophytes in ecological water treatment (Li et al. 2015a, b, c), see below).

"Microcystis aeruginosa is a species of freshwater cyanobacteria which can form harmful algal blooms of economic and ecological importance (Huo et al. 2015). Microcystis are the most common toxic cyanobacterial bloom in eutrophic fresh water. Cyanobacteria produce several groups of toxins, neurotoxins and peptide hepatotoxins, such as microcystin and cyanopeptolin". ${ }^{1}$ Several case studies have been reported recently in EES. Huang et al. (2014) investigated algal bloom and factors influencing its formation in Taihu Lake from 2000 to 2011. Thi Thuy et al. (2014) studied the occurrence of cyanobacteria and microcystins in the Hoan Kiem Lake and the Nui Coc reservoir (North Vietnam).

Macrophytes are aquatic plants that grow in or near water and are emergent, submergent, or floating. In lakes and rivers macrophytes provide cover for fish and substrate for aquatic invertebrates, produce oxygen and act as food for some fish and wildlife. ${ }^{2}$ Several case studies have been reported recently in EES from Brazil, India and Greece. Goldoni et al. (2014) investigated cytotoxic and genotoxic evaluation and chemical characterization of sewage treated using activated sludge and a floating emergent-macrophyte filter in a municipal wastewater treatment plant in Southern Brazil. Christia et al. (2014) studied seasonal and spatial variations of water quality, substrate and aquatic macrophytes based on side scan sonar, in an eastern Mediterranean lagoon (Kaiafas, Ionian Sea). Anshumali et al.

\footnotetext{
${ }^{1}$ https://en.wikipedia.org/wiki/Microcystis_aeruginosa.

${ }^{2}$ https://en.wikipedia.org/wiki/Macrophyte.
} 
(2014) investigated geochemical alterations in surface waters of Govind Ballabh Pant Sagar, Northern Coalfield, India. Bai et al. (2013) studied short-time response in growth and sediment properties of Zizania latifolia to water depth. Several EES works were discussing the role of algae communities in water treatment including biofilms (Wang et al. 2014; Elersek et al. 2014; Li et al. 2014; Hallmann et al. 2013).

As one of the most important territorial resources, lakes play an important role during the economic and social development in China. In recent decades, due to irrational patterns of economic and social development, fast urbanization and under-developed facilities for pollution treatment, many lakes in China suffered from nitrogen and phosphorus pollution. The problems of water pollution and eutrophication are therefore increasingly severe. A large number of lakes remains in a state of high ecological risk, with frequent algal blooms.

In light of the significant role lakes play in economic and social development of China and the severity of the contamination and eutrophication of these lakes, the Chinese government attached great importance to protecting Lake Environment and continued to commit increasing volumes of manpower and funds to this undertaking. Especially since the 11th five-year plan, the government has carried out major scientific programmes, such as the National Water Pollution Control and Treatment programme, to lead and drive the water pollution treatment of water basins. And some progress had been achieved. However, since China remains in a special stage during its fast social and economic development, the contradiction created by economic development and environmental protection cannot be eliminated in a short-time period. Therefore, the water pollution and eutrophication of lakes remains one of the major environmental issues in China (Wang et al. 2015b).

As one of the lake districts where the water pollution and eutrophication hit their worst, there are about 60 lakes larger than 1000 squares kilometres in Yunnan-Guizhou Plateau. The eutrophication problem of these lakes has become one of the major environmental issues that restrict local economic and social development. Due to its unusual geological and environmental conditions, the eutrophication mechanism in Yunnan-Guizhou Plateau is rather unique.

Dianchi Lake, the largest lake in Yunnan-Guizhou Plateau, was one of the most polluted shallow lakes in China (Fig. 1). It has a surface of $298 \mathrm{~km}^{2}$ at 1886 above sea level. The lake extends $39 \mathrm{~km}$ long from north to south with a width of $13.5 \mathrm{~km}$ and has an average depth of $4.4 \mathrm{~m}$. Lake Dianchi is the eighth largest lake in China, it is also denoted as the lake of Kunming, the capitol of the Yunnan province (Lu et al. 2013; Hou et al. 2014). Located in the lower reach of the cities and at the bottom of the valley, Dianchi Lake is situated in an area which is characterized with developed local economy, dense population, high

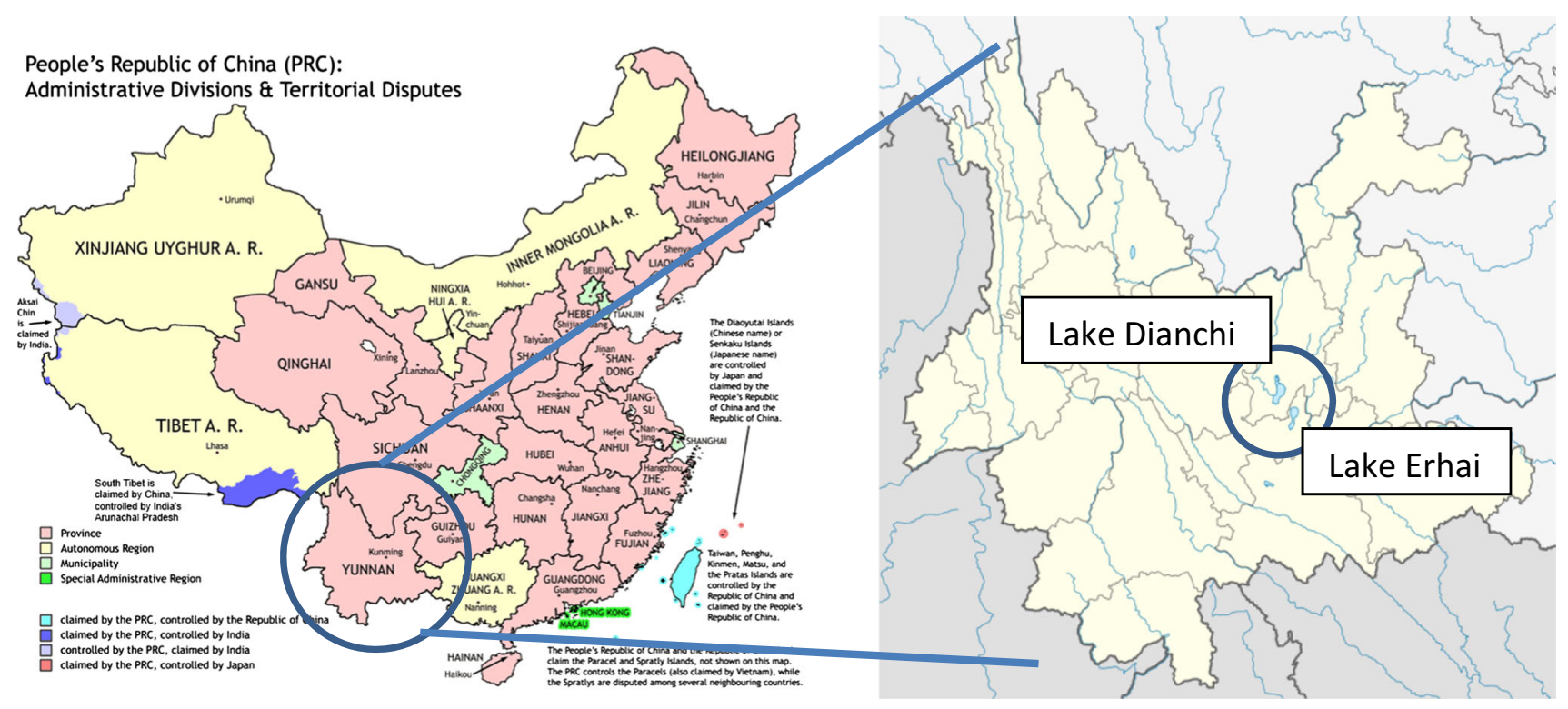

Fig. 1 Location of the study areas Lake Dianchi and Lake Erhai (see also China Maps statement on the journals webpages at http://www. springer.com/earth+sciences+and+geography/geology/journal/126 65). Sources: Left: Wikipedia, https://upload.wikimedia.org/wikipe dia/commons/c/c9/China_administrative.png, Right: China Yunnan location map"von NordNordWest-Eigenes Werk, using United
States National Imagery and Mapping Agency data World Data Base II data Yunnan province administrative regions GIS data: 1:1.000.000, County level, 1990. Lizenziert unter CC BY-SA 3.0 de über Wikimedia Commons_http://commons.wikimedia.org/wiki/ File:China_Yunnan_location_map.svg\#/media/File:China_Yunnan_ location_map.svg 
level of urbanization and severe water shortage. These make Dianchi Lake as one of the most difficult to treat in China. After years of effort, results have gradually been achieved in the treatment of Dianchi pollution (Liu et al. $2015 \mathrm{a}, \mathrm{b})$. The quantity of major water pollutants such as nitrogen and phosphorus has significantly dropped. The lake is highly polluted (worst water quality Grade V) as a result of pumping untreated water into the lake for many years. Another problem is the agricultural runoff into the lake (Ma and Wang 2015).

Lake Erhai is an alpine lake (at 1972 metres elevation above sea level) in the Yunnan province in China (Fig. 1). The lake stretches 40 kilometres length in North-South direction and is $7-8 \mathrm{~km}$ wide. With an area of about $250 \mathrm{~km}^{2}$ Lake Erhai is the second largest highland lake of China after Dianchi Lake. The lake contains about 2.5 billion cubic metres of water. Overall it has a high water quality. But high levels of nitrogen and phosphorus content exist in sediment. Its main biological groups have changed (Wang et al. 2015c). Currently, it is in the initial stage of eutrophication (He et al. 2015a, b) (Fig. 1).

In order to report the latest researching results on lake water pollution and eutrophication, and promote the prevention and treatment of Lake water pollution, supported by the "National Water Pollution Control and Treatment" programme, this thematic Issue of 26 articles took Dianchi and Erhai Lakes as examples to focus on the process and mechanism of aspects such as their water quality and evolution, sediment contamination $(\mathrm{Li}$ et al. 2015a, c; Wang et al. 2015c; Xue and Lu 2015; Zhang et al. 2015b), plankton (Ma et al. 2015b) and algae blooms (Ma et al. 2015a; Yang et al. 2015), fishery industry structure and aquatic plants (Yan et al. 2015). It systematically analysed the pollution process, stages characteristics and major biological group changes of Dianchi and Erhai Lakes ( $\mathrm{He}$ et al. 2015a). It also analysed the major problems such as the evolution of the basin's water environment, and its protection and treatment, in order to further promote and enhance the protection and treatment of Dianchi, Erhai and other lakes in China (Wang et al. 2015a; Zhang et al. 2015a, b; Zhu et al. 2015).

Acknowledgments Chinese lakes-here the Dianchi Lake became an important research object worldwide. Within the German research initiative CLIENT (International Partnership for sustainable climate protection as well as environmental technologies and services) funded by German Federal Ministry of Education and Research (BMBF) several projects started recently to support China in solving the water problems, e.g. SinoWater (coordinated by RWTH Aachen), SIGN (coordinated by TZW Karlsruhe) and Urban Catchments (coordinated by Helmholtz Centre for Environmental Research UFZ and TU Dresden). The funding of the German-Chinese cooperation projects by BMBF and Chinese Ministry of Science and Technology based on the joint declaration of 07.05.2015 is very much appreciated.

\section{References}

Anshumali RM, Yadav SK et al (2014) Geochemical alterations in surface waters of Govind Ballabh Pant Sagar, Northern Coalfield, India. Environ Earth Sci 71(7):3181-3193. doi:10.1007/ s12665-013-2706-3

Antunes M, Antunes MT, Fernandes AN et al (2013) Nutrient contents in bottom sediment samples from a southern Brazilian microbasin. Environ Earth Sci 69(3):959-968

Bai X, Chen K, Chen X (2013) Short-time response in growth and sediment properties of Zizania latifolia to water depth. Environ Earth Sci 70(6):2847-2854

Beinhorn M, Dietrich P et al (2005) 3-D numerical evaluation of density effects on tracer tests. J Contam Hydrol 81(1-4):89-105

Beyer C, Bauer S et al (2006) Uncertainty assessment of contaminant plume length estimates in heterogeneous aquifers. J Contam Hydrol 87(1-2):73-95

Chen Y, Chen S, Yu S et al (2014) Distribution and speciation of phosphorus in sediments of Dongping Lake, North China. Environ Earth Sci 72(8):3173-3182

Christia C, Papastergiadou E, Papatheodorou G et al (2014) Seasonal and spatial variations of water quality, substrate and aquatic macrophytes based on side scan sonar, in an eastern Mediterranean lagoon (Kaiafas, Ionian Sea). Environ Earth Sci 71(8):3543-3558

Dimberg PH, Bryhn AC (2014) Predicted effects from abatement action against eutrophication in two small bays of the Baltic Sea. Environ Earth Sci 72(4):1191-1199

Duong TT, Jaehnichen S, Le TPQ et al (2014) The occurrence of cyanobacteria and microcystins in the Hoan Kiem Lake and the Nui Coc reservoir (North Vietnam). Environ Earth Sci 71(5):2419-2427

Elersek T, Mulec J (2014) The algal community at an ecocline of a cold sulphidic spring (Sovra artesian borehole, Slovenia). Environ Earth Sci 71(12):5255-5261

George R, Muraleedharan KR, Martin GD et al (2013) Nutrient biogeochemistry of the eastern Arabian Sea during the southwest monsoon retreat. Environ Earth Sci 68(3):703-718

Goldoni A, Golfeto C, Teixeira JB et al (2014) Cytotoxic and genotoxic evaluation and chemical characterization of sewage treated using activated sludge and a floating emergent-macrophyte filter in a municipal wastewater treatment plant: a case study in Southern Brazil. Environ Earth Sci 72(5):1503-1509

Grathwohl P, Ruegner H, Woehling T et al (2013) Catchments as reactors: a comprehensive approach for water fluxes and solute turnover. Environ Earth Sci 69(2):317-333

Hallmann C, Wedekind W, Hause-Reitner D et al (2013) Cryptogam covers on sepulchral monuments and re-colonization of a marble surface after cleaning. Environ Earth Sci 69(4):1149-1160

Harmon TS, Smoak JM, Waters MN et al (2014) Hydrologic fragmentation-induced eutrophication in Dove Sound, Upper Florida Keys, USA. Environ Earth Sci 71(10):4387-4395

He J, Deng W, Chen C, Xu X, Wang S, Liu W, Wu X (2015a) Phosphorus adsorption and release characteristics of surface sediments in Dianchi Lake, China. Environ Earth Sci. doi:10. 1007/s12665-015-4723-x

He L, Zhu T, Cao T, Li W, Zhang M, Zhang X, Ni L, Xie P (2015b) Characteristics of early eutrophication encoded in submerged vegetation beyond water quality: a case study in Lake Erhai. Environ Earth Sci, China. doi:10.1007/s12665-015-4202-4

Hou D, He J, Lu C et al (2014) Spatial variations and distributions of phosphorus and nitrogen in bottom sediments from a typical north-temperate lake China. Environ Earth Sci 71(7):3063-3079

Huang C, Li Y, Yang H et al (2014) Detection of algal bloom and factors influencing its formation in Taihu Lake from 2000 to 2011 by MODIS. Environ Earth Sci 71(8):3705-3714 
Huo S, Ma C, He Z, Xi B, Su J, Zhang L, Wang J (2015) Prediction of physico-chemical variables and chlorophyll a criteria for ecoregion lakes using the ratios of land use to lake depth. Environ Earth Sci. doi:10.1007/s12665-015-4020-8

Ivashechkin P, Corvini PFX, Dohmann M (2004) Behaviour of endocrine disrupting chemicals during the treatment of municipal sewage sludge. Water Sci Technol 50(5):133-140

Ji D, Xi B, Su J et al (2014) Structure equation model-based approach for determining lake nutrient standards in Yungui Plateau ecoregion and Eastern Plain ecoregion lakes, China. Environ Earth Sci 72(8):3067-3077

Kalbacher T, Delfs J-O, Shao H et al (2012) The IWAS-ToolBox: software coupling for an integrated water resources management. Environ Earth Sci 65(5):1367-1380

Kalbus E, Kalbacher T et al (2012) Integrated water resources management under different hydrological, climatic and socioeconomic conditions. Environ Earth Sci 65(5):1363-1366

Li H, Rao B, Wang G et al (2014) Spatial heterogeneity of cyanobacteria-inoculated sand dunes significantly influences artificial biological soil crusts in the Hopq Desert (China). Environ Earth Sci 71(1):245-253

Li L, Liu L, Wang S, Liu W, Jiao L, Yang Y, Yang R (2015a) Spatial distribution of phosphorus fractions in sediment and the potential mobility of phosphorus in Dianchi Lake. Environ Earth Sci. doi:10.1007/s12665-015-4151-y

Li Y, Wang S, Zhang L (2015b) Composition, source characteristic and indication of eutrophication of dissolved organic matter in the sediments of Erhai Lake. Environ Earth Sci. doi:10.1007/ s12665-014-3964-4

Li W, Cao T, Ni L, Zhu G, Zhang X, Fu H, Song X, Xie P (2015c) Size-dependent $\mathrm{C}, \mathrm{N}$ and $\mathrm{P}$ stoichiometry of three submersed macrophytes along water depth gradients. Environ Earth Sci. doi:10.1007/s12665-015-4295-9

Liu S, Chang N-B (2013) Geochemical impact of aquifer storage and recovery operation on fate and transport of sediment phosphorus in a large shallow lake. Environ Earth Sci 68(1):189-201

Liu W, Wang S, Zhang L, Ni Z, Zhao H, Jiao L (2015a) Phosphorus release characteristics of sediments in Erhai Lake and their impact on water quality. Environ Earth Sci. doi:10.1007/s12665015(ENGE-D-15-00266)

Liu W, Wang S, Zhang L, Ni Z (2015b) Water pollution characteristics of Dianchi Lake and the course of protection and pollution management. Environ Earth Sci. doi:10.1007/s12665-015-4152-x

Lu S, Jin X, Liang L et al (2013) Influence of inactivation agents on phosphorus release from sediment. Environ Earth Sci 68(4):1143-1151

Ma G, Wang S (2015) Temporal and spatial distribution changing characteristics of exogenous pollution load into Dianchi Lake, Southwest of China. Environ Earth Sci. doi:10.1007/s12665015-4721-Z

Ma X, Wang Y, Feng S, Wang S (2015a) Comparison of four flocculants for removing algae in Dianchi Lake. Environ Earth Sci. doi:10.1007/s12665-015-4093-4

Ma X, Wang Y, Feng S, Wang S (2015b) Vertical migration patterns of different phytoplankton species during a summer bloom in Dianchi Lake, China. Environ Earth Sci. doi:10.1007/s12665015-4279-9

Marjore A, Maisa Trevisan A, Andreia Neves F et al (2013) Nutrient contents in bottom sediment samples from a southern Brazilian microbasin. Environ Earth Sci 69(3):959-968. doi:10.1007/ s12665-012-1980-9

Renjith KR, Joseph MM, Ghosh P et al (2013) Biogeochemical facsimile of the organic matter quality and trophic status of a micro-tidal tropical estuary. Environ Earth Sci 70(2):729-742

Rink K, Kalbacher $\mathrm{T}$ et al (2012) Visual data exploration for hydrological analysis. Environ Earth Sci 65(5):1395-1403
Rinke K, Kuehn B, Bocaniov S et al (2013) Reservoirs as sentinels of catchments: the Rappbode Reservoir Observatory (Harz Mountains, Germany). Environ Earth Sci 69(2):523-536

Sedlacek J, Babek O, Grygar TM (2013) Trends and evolution of contamination in a well-dated water reservoir sedimentary archive: the Brno Dam, Moravia, Czech Republic. Environ Earth Sci 69(8):2581-2593

Wang T, Yunkai L, Mingchao L et al (2014) Biofilms on the surface of gravels and aquatic plants in rivers and lakes with reusing reclaimed water. Environ Earth Sci 72(3):743-755

Wang D, Nie E, Luo X, Yang Liu Q, Zheng Z (2015a) Study of nitrogen removal performance in pilot-scale multi-stage vermibiofilter: operating conditions impacts and nitrogen speciation transformation. Environ Earth Sci. doi:10.1007/s12665-0154713-z

Wang S, Meng W, Jin XC, Zheng BH, Zhang L, Xi HY (2015b) Ecological security problems of the major key lakes in China. Environ Earth Sci. doi:10.1007/s12665-015-4191-3

Wang S, Zhang L, Ni L, Zhao H, Jiao L, Yang S, Guo L, Shen J (2015c) Ecological degeneration of the Erhai Lake and prevention measures. Environ Earth Sci. doi:10.1007/s12665-015-4433-4

Wang S, Zhao Y, Jiao L, Zhang L, Guo W (2015d) Characteristics of soluble organic nitrogen composition and sources in sediments from Erhai Lake in China and the effect on the water quality. Environ Earth Sci. doi:10.1007/s12665-015-4107-2

Watchorn MA, Hamilton PB, Patterson RT (2013) The paleolimnology of Haynes Lake, Oak Ridges Moraine, Ontario, Canada: documenting anthropogenic and climatic disturbances. Environ Earth Sci 68(7):1823-1834

Wu Lei, Long Tian-yu, Liu Xia et al (2013) Modeling impacts of sediment delivery ratio and land management on adsorbed nonpoint source nitrogen and phosphorus load in a mountainous basin of the Three Gorges reservoir area, China. Environ Earth Sci 70(3):1405-1422

Xue W, Lu SY (2015) Effects of inactivation agents and temperature on phosphorus release from sediment in Dianchi Lake, China. Environ Earth Sci. doi:10.1007/s12665-014-3910-5

Yan K, Duan C, Fu D, Li J, Wong MHG, Qian L, Tian Y (2015) Leaf nitrogen and phosphorus stoichiometry of plant communities in geochemically phosphorus-enriched soils in a subtropical mountainous region, SW China. Environ Earth Sci. doi:10.1007/ s12665-015-4519-z

Yang S, Jin W, Wang S, Hao X, Yan Y, Zhang M, Zheng B (2015) Chlorophyll ratio analysis of the responses of algae communities to light intensity in spring and summer in Lake Erhai. Environ Earth Sci. doi:10.1007/s12665-015-4140-1

Yuan H, An S, Shen J et al (2014) The characteristic and environmental pollution records of phosphorus species in different trophic regions of Taihu Lake, China. Environ Earth Sci 71(2):783-792

Zhang L, Wang S, Li Y, Zhao H, Qian W (2015a) Spatial and temporal distributions of microorganisms and their role in the evolution of Erhai Lake eutrophication. Environ Earth Sci. doi:10.1007/s12665-015-4136-x

Zhang Y, Huo S, Zan F, Xi B, Zhang J, Wu F (2015b) Historical records of multiple heavy metals from dated sediment cores in Lake Chenghai, China. Environ Earth Sci. doi:10.1007/s12665014-3858-5

Zhu Y, Zhang R, Wu F et al (2013) Phosphorus fractions and bioavailability in relation to particle size characteristics in sediments from Lake Hongfeng, Southwest China. Environ earth Sci 68(4):1041-1052

Zhu G, Zhang M, Cao T, Ni L (2015) Associations between the morphology and biomechanical properties of submerged macrophytes: implications for its survival and distribution in Lake Erhai. Environ Earth Sci. doi:10.1007/s12665-015-4267-0 